\title{
Big Data In Agriculture (BDA)
}

DOI: http://doi.org/10.26480/bda.02.2020.69.73

\section{ZIBELINE INTERNATIONAL ISSN: 2682-7786 (Online) CODEN: BDAIDR}

RESEARCH ARTICLE

\section{STUDY OF COMBINED MAGNETIZED WATER AND SALINITY ON SOIL PERMEABILITY IN NORTH OF IRAN}

\author{
Masoud Pourgholam-Amijia*, Mojtaba Khoshravesh ${ }^{b}$, Muhammad Mohsin Waqasc, Sayyed Mohammad Javad Mirzaei ${ }^{\mathrm{d}}$ \\ a Department of Irrigation and Reclamation Engineering, College of Agriculture and Natural Resources, University of Tehran, Karaj, Iran. \\ ${ }^{b}$ Water Engineering Department, Faculty of Agricultural Engineering, Sari Agricultural Sciences and Natural Resources University, Sari, Iran. \\ c Department of Agricultural Engineering, Khwaja Fareed University of Engineering and Information Technology, Rahim Yar Khan, Pakistan \\ ${ }^{d}$ Department of Water Engineering, Faculty of Agriculture, University of Torbat-e Jam, Iran. \\ *Corresponding Author Email: Mpourgholam6@ut.ac.ir
}

This is an open access article distributed under the Creative Commons Attribution License CC BY 4.0, which permits unrestricted use, distribution, and reproduction in any medium, provided the original work is properly cited.

\section{ARTICLE DETAILS}

\section{Article History:}

Received 25 March 2020

Accepted 28 April 2020

Available online 29 June 2020

\begin{abstract}
The leaching of salts through facilitating the permeability process is very important for irrigation systems planning. The negative effect of soil compaction on plant growth is an integration of multidirectional influences, such as the reduction of aeration to the roots. This research was done at Babolsar city, Mazandaran province, Iran to investigate the effect of magnetized water and different irrigation water salinity treatments on cumulative and final infiltration rate and soil electrical conductivity. The experimental treatments include magnetized and non-magnetized irrigation water, different level of irrigation water salinity $\left(0.58 \mathrm{dSm}^{-1}, 6.5\right.$ $\mathrm{dSm}^{-1}$, and $13 \mathrm{dSm}^{-1}$ ) and variable soil texture (loamy-sand, loam, and clay). The factorial experiment was conducted with a complete randomized block design with three replications. Magnetized water was obtained by passing the water via a strong magnetic field installed on the irrigation pipeline. The results exposed that the effects of soil texture and magnetized irrigation water on the final infiltration rate and cumulative infiltration were significant $(\mathrm{P}<0.01)$. Final infiltration rates and cumulative infiltration in magnetized water treatment was greater than non-magnetized treatment. The magnetized irrigation water had the most effect on the infiltration capacity of clay soil. Also, the results showed that magnetized water could decrease soil electrical conductivity in the soil profile, and this effect at a $1 \%$ level was significant. It was concluded that magnetized water can be used as an effective technique for desalinization in agriculture.
\end{abstract}

\section{KEYWORDS}

Electrical Conductivity, Infiltration Rate, Soil Texture, Water Salinity, Magnetized Water.

\section{INTRODUCTION}

Infiltration is the downward movement of water into the soil. Understanding the influential factors and processes governing water infiltration in the soil is of special importance because by recognizing these factors, it is possible to examine the optimal water management in farms and by achieving sufficient knowledge in this field, better environmental programs Executed (Chen et al., 2018; Gelaye et al., 2019; Liu et al., 2020). Also, the infiltration has an effective role in the hydrologic cycle, regional ecology, runoff rate, soil erosion and degradation, solute transport, and groundwater pollution (Ajwa et al., 2006; Fentaw et al., 2018). Understanding the infiltration process is necessary for planning and management in irrigation systems (Radcliffe and Rasmussen, 2000; Khoshravesh et al., 2011; Javadinejad et al., 2019). Due to water scarcity, it seems necessary to use non-conventional water such as salt water. Therefore, in this study, the combination of magnetized water and salinity on soil permeability will be investigated.

From an agricultural point of view, infiltration is an important physical property of soils (Lit et al., 2020). Irrigation system type selection for an area depends on water infiltration features. The infiltration rate depends on factors such as soil physical properties, initial soil moisture content, slope and surface roughness of soil, percentage, and type of vegetation, and water quality. The infiltration slow rates on the fields can result in the high runoff, requiring longer irrigation durations and a greater frequency to meet irrigation demands. Slow infiltration on the fields with surface irrigation can consequence in crop damage due to inadequate aeration in the root zone, and can even result in algae growth on the soil surface (Ajwa and Trout, 2006). In arid and semi-arid regions, farmers use low-quality groundwater because of the limited availability of good-quality irrigation water; instead, magnetized water can be used for irrigation given its better quality (Gelaye et al., 2019; Fentaw et al., 2018). Magnetized water is obtained by passing the water via permanent magnets or through electromagnets installed on a feeding pipeline (Khoshravash et al., 2011).

Water scarcity and soil salinity are the two main issues of restrictive sustainable agriculture in the arid and semiarid areas in the world (Chen et al., 2010; Javadinejad et al., 2019; Kang et al., 2017). Also, soil salinity is one of the most important issues that restrict the development of plants cultivation. The irrigation water quality has an important impact on growth of plants, yield, productivity and other soil physical conditions (Krouma 2009; Öğütçü et al., 2010). Therefore, it is vital to use saline water efficiently to supply agricultural irrigation provided that avoiding secondary salinity (Chen et al., 2018).

Magnetic water is gotten bypassing of water via a magnetic field by 
permanent ceramic magnets installed around the incoming water pipe (Du Toit et al., 2009). When water passes via the magnetic field, some physical properties such as salt solubility capacity, density, and deposition ratio of solid particles will change (Higashitani et al., 1993; Khoshravesh et al., 2011; Mohamed and Ebead, 2013). When water is exposed to a magnetic field, it causes changes in its properties including viscosity, dielectric constant, surface tension force, the boiling and freezing points, and electric conductivity compared to pure water (XiaoFeng and Bo, 2008). Thus, magnetized water has wide applications in different sectors (Fathi et al., 2006; Kney and Parsons, 2006).

Ghauri and Ansari showed that a relatively weak magnetic field increased the viscosity of water, which was ensured by the stronger hydrogen bonds under the magnetic field (Ghauri and Ansari, 2006). Jacob showed that the use of magnetically treated water can be improved the water quality of irrigation (Jacob, 1999). A studied the effect of solubility of $\mathrm{NaCl}$ and $\mathrm{Na}_{2} \mathrm{CO}_{3}$ salts in the magnetized water and proposed to use magnetized water for leaching of saline or alkaline soils (Srivastava et al., 1976). A group researchers showed that irrigation with magnetized water improved soil moisture up to $7.5 \%$ as compared to the non-magnetized water and this increase was significant $(\mathrm{P}<0.01)$ (Mostafazadeh-Fard et al., 2011).

A group researchers examined the effects of magnetized water on the distribution pattern of soil water with respect to time in trickle irrigation (Khoshravesh et al., 2011). The results show that the differences in soil moisture for days 1, 2 and 3 after irrigation with magnetized irrigation water were lesser than those for the non-magnetized irrigation water treatments. In other study, researchers also examined a novel phytoremediation method assisted by magnetized water to decontaminate soil $\mathrm{Cd}$ based on harvesting senescent and dead leaves of Festuca arundinacea (Luo et al., 2020). The results showed that after irrigation with magnetized water, the biomass of senescent and dead leaves increased from 15.7 and $6.4 \%$ to 17.2 and $11.6 \%$, respectively, and a significantly higher amount of $\mathrm{Cd}(\sim 23.6 \%)$ was redistributed into dead leaves compared with the control.

As water scarcity increases and agricultural products need more water, farmers use low-quality surface and groundwater, which is detrimental to soil health and reduces crop yields. Therefore, magnetic irrigation is a method that can be used in agriculture by improving water quality as well as desalination of saline water, and in this way, will improve the condition of water resources. To date, there is a few research about the effects of magnetized saline water on soil Permeability capacity. The objective of the present research was to investigate soil infiltration capacity under different level of saline water using magnetized water in different soil textures.

\section{Materials AND MethodS}

In this study, three different agricultural fields were selected at Babolsar city, Mazandaran province, Iran. Figure 1 shows the geographical location of the study area. Physical soil properties in these fields are shown in Table 1. In each field, three points were selected, and a double-ring instrument was used to measure the infiltration rate.

Table 1: Some physical characteristics of the selected soils

\begin{tabular}{|l|c|c|c|c|c|}
\hline Texture & $\begin{array}{l}\text { Clay } \\
(\%)\end{array}$ & $\begin{array}{l}\text { Silt } \\
(\%)\end{array}$ & $\begin{array}{l}\text { Sand } \\
(\%)\end{array}$ & $\begin{array}{l}\text { Porosity } \\
(\%)\end{array}$ & $\begin{array}{l}\text { Bulk density } \\
(\mathrm{gr} / \mathrm{cm} 3)\end{array}$ \\
\hline Loamy-Sand & 9.5 & 10.1 & 80.4 & 27.54 & 1.78 \\
\hline Loam & 20.6 & 49.8 & 29.6 & 34.61 & 1.62 \\
\hline Clay & 52.3 & 26.2 & 21.5 & 39.88 & 1.49 \\
\hline
\end{tabular}

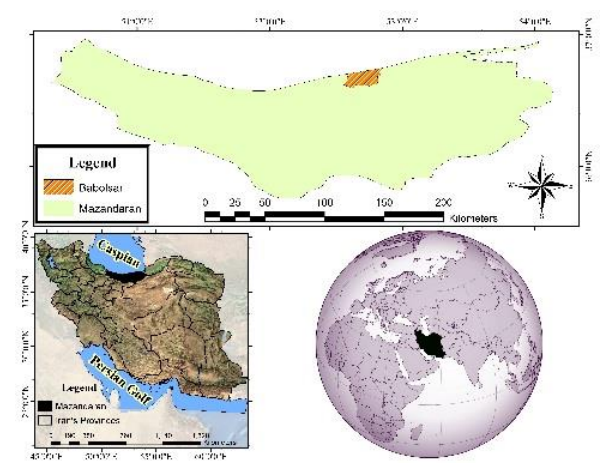

Figure 1: Geographical location of the study area
The inner and outer rings had a diameter of 25 and $50 \mathrm{~cm}$, respectively. The double-ring was installed on surface soil which was almost free of vegetation, without cracks, unplowed, and relatively flat slope. Upon penetrating $10 \mathrm{~cm}$ of the rings into the soil, the protective and inner rings were filled with water and the falling of water level was measured with time. Throughout the experiments, the minimum depth of water in cylinders was held at a level of $10 \mathrm{~cm}$. After 4 hours, the infiltration rate reached almost to a constant value. Using these measurements, the infiltration rate at any given moment, the final infiltration rate (also called infiltration capacity), and also accumulated depth of water was calculated.

The average infiltration rate for an interval of time is calculated as:

$$
f=\frac{z_{n}-z_{n}-1}{t_{n}-t_{n}-1}
$$

Where, $f$ is the average infiltration rate $(\mathrm{cm} / \mathrm{min}), z_{n}$ is cumulative infiltrated depth at time $t_{n}(\mathrm{~cm}), z n-1$ is cumulative infiltrated depth at time $t_{n-1}(\mathrm{~cm})$, and $t$ and $t_{n-1}$ are time (min).

The experimental treatments were types of irrigation water (W1= magnetized and $\mathrm{W} 2=$ non-magnetized water), irrigation water salinity $\left(\mathrm{S} 1=0.58 \mathrm{dSm}^{-1}, \mathrm{~S} 2=6.5 \mathrm{dSm}^{-1}\right.$ and $\left.\mathrm{S} 3=13 \mathrm{dSm}^{-1}\right)$ and soil texture (T1= loamy-sand, $\mathrm{T} 2=\mathrm{loam}$, and $\mathrm{T} 3=$ clay). The factorial experiment was laid out with a complete randomized block design with three replications.

The changes produced by the magnetic water depend on many aspects, such as direction and strength of the magnetic field, a flow rate of the solution, duration of operation and acidity (Baker and Judd 1996; Parsons et al. 1997; Gabrielli et al. 2001; Chibowski et al. 2005). To create a magnetic field, a permanent ceramic type magnet was used in the irrigation system. Magnetized water was obtained bypassing water through the magnet with the trade name of Saba Poul and a strength of 0.3 Tesla was installed on the main pipe. The North Pole and the South Pole were located in the top and the down of the pipe respectively, in the way different pole were close together. The arrangement of the north and the south poles and the direction of the magnetic field generated are shown in Figure 2. The device consists of a $400 \mathrm{~mm}$ long polycarbonate pipe with an internal diameter of $60 \mathrm{~mm}$. The permanent magnets were made of Neodymium Ferrite Boron (NdFeB).

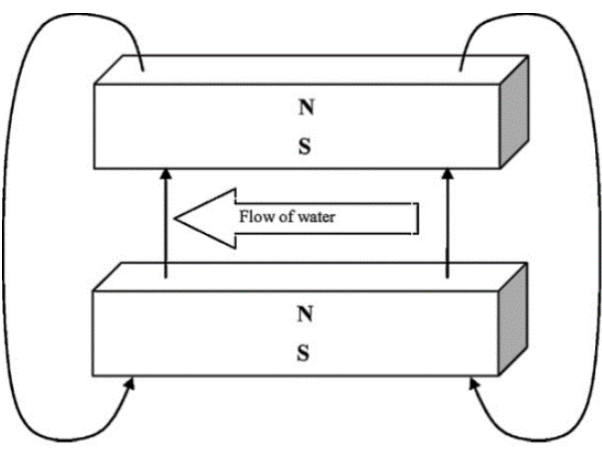

Figure 2: The magnetic device with two permanent magnets showing their north and south poles

The values of the magnetic field intensity $(\mathrm{Bx})$ generated by the two magnets varied from 0.006 to 0.2855 Tesla along the axis pipe (centerline). The intensity was measured along with the longitudinal and cross-sectional directions of the pipe using a Tesla meter (Magna-MG 701). For the magnetically treated water, the irrigation water was exposed to a static non-uniform magnetic field for about $0.4 \mathrm{~s}$ by passing water through the magnetic treatment device with magnetic induction in the range of 0.006-0.2855 Tesla. The final infiltration rate, the cumulative water infiltration depth, and soil salinity were analyzed using Excel and SAS software. Mean values Comparison for each treatment was performed with the LSD test at $1 \%$ and $5 \%$ significance levels.

\section{RESULTS AND DisCUSSION}

Variance analysis displayed that the effects of soil texture, irrigation water salinity, and magnetized water on the final rate of infiltration and cumulative infiltration were significant at $1 \%$ probability level. But there was no significant effect in irrigation water salinity treatment on the final infiltration rate and cumulative infiltration. The combined effects of treatments including, irrigation water and soil texture, irrigation water 
and irrigation water salinity, soil texture, and irrigation water salinity on final infiltration rate and cumulative infiltration were not significant (Table 2).

\begin{tabular}{|l|c|c|c|}
\hline \multicolumn{4}{|c|}{ Table 2: Variance analysis for the parameters } \\
\hline \multirow{2}{*}{ Parameter } & \multirow{2}{*}{ Degrees of freedom } & \multicolumn{2}{c|}{ Mean squares } \\
\cline { 3 - 4 } & & fc & $\mathrm{F}$ \\
\hline block & 2 & 0.0043 & 0.213 \\
\hline $\mathrm{T}$ & 2 & $0.083^{* *}$ & $476.08^{* *}$ \\
\hline $\mathrm{W}$ & 1 & $0.189^{* *}$ & $1011.21^{* *}$ \\
\hline $\mathrm{S}$ & 2 & $0.016^{\text {ns }}$ & $16.13^{\text {ns }}$ \\
\hline $\mathrm{T} \times \mathrm{W}$ & 2 & $0.009^{\text {ns }}$ & $89.95^{* *}$ \\
\hline $\mathrm{T} \times \mathrm{S}$ & 4 & $0.006^{\text {ns }}$ & $19.87^{\text {ns }}$ \\
\hline $\mathrm{S} \times \mathrm{W}$ & 2 & $0.012^{\text {ns }}$ & $9.14^{\text {ns }}$ \\
\hline $\mathrm{T} \times \mathrm{W} \times \mathrm{S}$ & 4 & $0.016^{\text {ns }}$ & $34.66^{\text {ns }}$ \\
\hline Error & 34 & 0.01 & 17.59 \\
\hline
\end{tabular}

Note: ${ }^{* *}, *$ and ns represent significance at $1 \%$ level, significance at $5 \%$ level, and non-significant, respectively.

Comparison of the final infiltration rate and the cumulative water infiltration showed that the final infiltration rate and cumulative water infiltration for magnetized water were better than non-magnetized water. Also, the final infiltration rate and cumulative water infiltrated were significantly different among all soil textures and types of irrigation water treatments $(\mathrm{P}<0.05)$. Among the soil textures, loamy sand had the highest cumulative water infiltrated (Table 3).

\begin{tabular}{|l|l|l|}
\hline \multicolumn{3}{|c|}{$\begin{array}{c}\text { Table 3: The comparison of average final infiltration rate and } \\
\text { cumulative water infiltration for different treatments }\end{array}$} \\
\hline \multirow{2}{*}{ Treatment } & $\begin{array}{l}\mathrm{f}_{\mathrm{c}} \\
(\mathrm{cm} / \mathrm{min})\end{array}$ & $\begin{array}{l}\mathrm{F} \\
(\mathrm{cm})\end{array}$ \\
\hline Soil texture & & \\
\hline $\mathrm{T}_{1}$ & $0.0575 \mathrm{a}$ & $34.12 \mathrm{a}$ \\
$\mathrm{T}_{2}$ & $0.0391 \mathrm{~b}$ & $21.41 \mathrm{~b}$ \\
\cline { 2 - 3 } $\mathrm{T}_{3}$ & $0.0308 \mathrm{c}$ & $17.56 \mathrm{c}$ \\
\hline Type of irrigation water & & \\
\hline $\mathrm{W}_{1}$ & $0.0532 \mathrm{a}$ & $28.98 \mathrm{a}$ \\
$\mathrm{W}_{2}$ & $0.0302 \mathrm{~b}$ & $18.46 \mathrm{~b}$ \\
\hline Irrigation water salinity & & \\
\hline $\mathrm{S}_{1}$ & & $25.25 \mathrm{a}$ \\
$\mathrm{S}_{2} \mathrm{~S}_{3}$ & $0.0461 \mathrm{a}$ & $24.88 \mathrm{a}$ \\
\cline { 2 - 3 } & $0.0432 \mathrm{a}$ & $24.59 \mathrm{a}$ \\
\cline { 2 - 3 } & $0.0405 \mathrm{a}$ & \\
\hline
\end{tabular}

In each column, means followed by the same letter are not significantly different at $5 \%$ level.

Figures 3,4 , and 5 show the comparison of cumulative infiltration versus time between magnetized and non-magnetized water in loamy-sand, loam, and clay soil, respectively. It is clear in Figure 3 that cumulative infiltration in magnetized water treatment is greater than that of non-magnetized water treatment. This difference in infiltration is obvious from the early moments of the experiment.

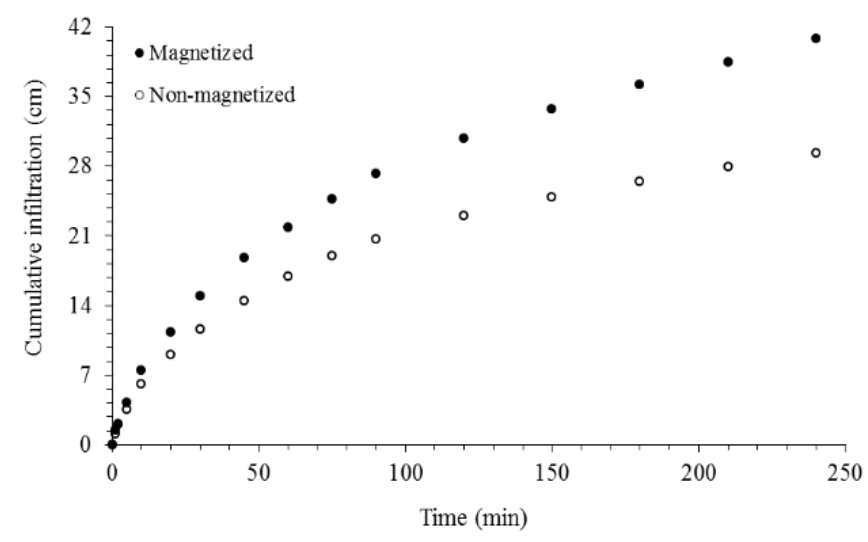

Figure 3: Cumulative water infiltration variation versus time for magnetized and non-magnetized water in loamy sand soil
As seen in Figures 3 to 5, the vertical distance (the difference of cumulative infiltration $(\mathrm{cm})$ ) between the magnetized and non-magnetized treatments is reduced from fine-textured to coarse-texture soils. This could be interpreted that the magnetic field has the most effect on cumulative infiltration is in fine-textured soils.

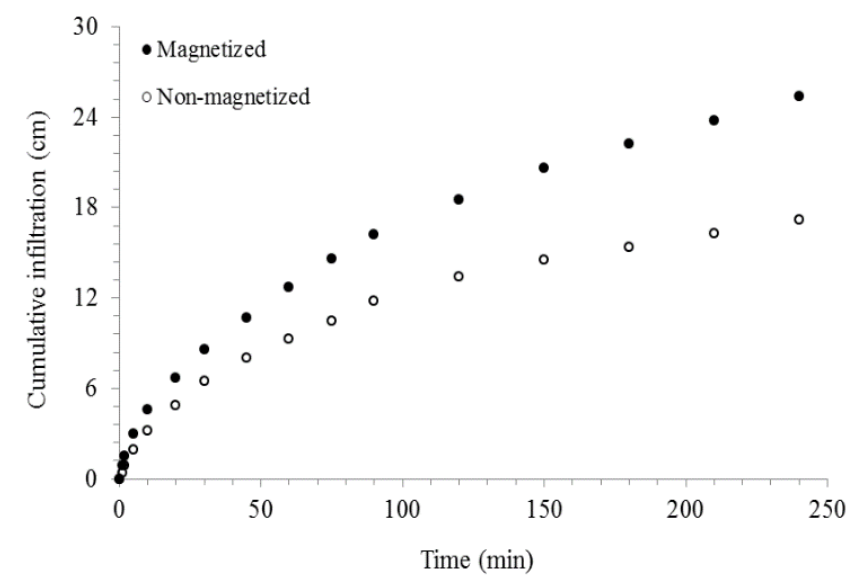

Figure 4: Cumulative water infiltration variation versus time for magnetized and non-magnetized water in loam soil

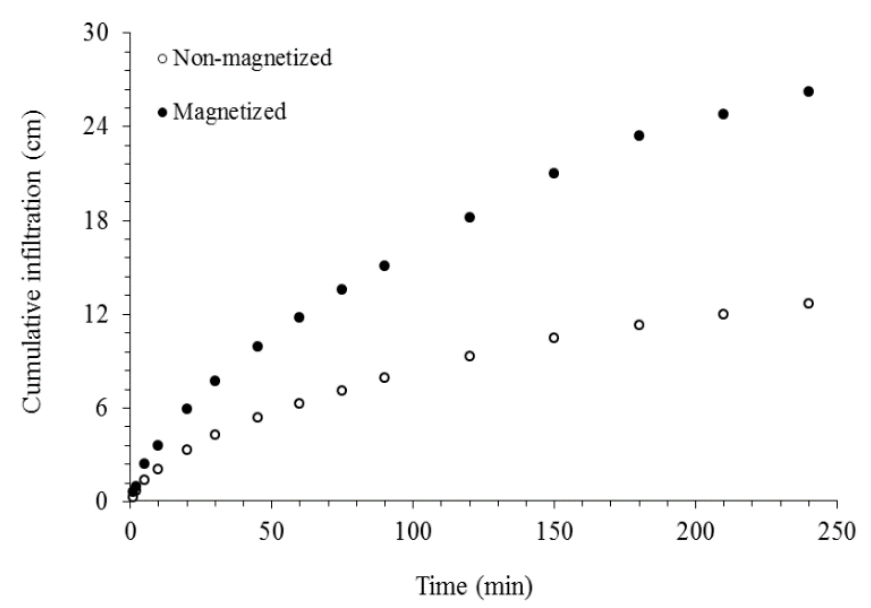

Figure 5: Cumulative water infiltration variation versus time for magnetized and non-magnetized water in clay soil

There are two reasons for the greater infiltration of magnetized irrigation water in comparison with non-magnetized irrigation water. First, under magnetized conditions, the water molecules which have been influenced by hydrogen bonds and Van der Waals forces and were in reactions with the ions are released and become more cohesive (Dobrevski et al., 1993; Madsen, 1995; Madsen, 2004). Therefore, the water molecules simply attribute to the soil particles and do not transfer to the lower soil depths. Also, the water molecules easily infiltrate into the micro spaces of the soil particles (Jacob, 1999; Madsen, 2004; Hozayn and Qados, 2010; Mostafazadeh-Fard et al., 2011). Second, changes in structure and physical characteristics took place when water passes via a magnetic field. Magnetized water causes a reduction in the existing free gases in water (Jacob, 1999).

Therefore, the matric suction of soil is increased with magnetized water, and thereby water infiltration increases. Due to higher matric suction in the clay soil, as compared to the loamy-sand and loam soils, the increase in water infiltration with magnetized water is more pronounced. Some researchers stated that the surface tension reduction observed in magnetic water results in better infiltration of water and in water and chemical use (Goldsworthy et al., 1999). The final infiltration rates after 4 hours of running the experiments for different treatments are shown in Table 4. In this table, it is obvious that the infiltration rates in magnetized water treatment are greater than that of non-magnetized water. As seen in Table 4, the infiltration rate $(\mathrm{cm} / \mathrm{min})$ difference between magnetized and non-magnetized water treatments is reduced from fine-textured to coarse-texture soils. Again, this means that the magnetic effect on water infiltration rate is the most effective in fine-textured soils. 
Table 4: Final infiltration rates, after 4 hours of running the experiments, for different treatments $(\mathrm{cm} / \mathrm{min})$

\begin{tabular}{|l|c|l|l|l|l|}
\hline Treatments & $\begin{array}{l}\text { Cumulative } \\
\text { infiltration }\end{array}$ & $\begin{array}{l}\text { Infiltration } \\
\text { rate }\end{array}$ & Treatments & $\begin{array}{l}\text { Cumulative } \\
\text { infiltration }\end{array}$ & $\begin{array}{l}\text { Infiltration } \\
\text { rate }\end{array}$ \\
\hline $\mathrm{W}_{1} \mathrm{~S}_{1} \mathrm{~T}_{1}$ & 40.8 & 0.076 & $\mathrm{~W}_{2} \mathrm{~S}_{1} \mathrm{~T}_{1}$ & 29.3 & 0.046 \\
\hline $\mathrm{W}_{1} \mathrm{~S}_{1} \mathrm{~T}_{2}$ & 25.4 & 0.053 & $\mathrm{~W}_{2} \mathrm{~S}_{1} \mathrm{~T}_{2}$ & 17.2 & 0.030 \\
\hline $\mathrm{W}_{1} \mathrm{~S}_{1} \mathrm{~T}_{3}$ & 26.2 & 0.046 & $\mathrm{~W}_{2} \mathrm{~S}_{1} \mathrm{~T}_{3}$ & 12.7 & 0.022 \\
\hline $\mathrm{W}_{1} \mathrm{~S}_{2} \mathrm{~T}_{1}$ & 40.4 & 0.073 & $\mathrm{~W}_{2} \mathrm{~S}_{2} \mathrm{~T}_{1}$ & 29.1 & 0.046 \\
\hline $\mathrm{W}_{1} \mathrm{~S}_{2} \mathrm{~T}_{2}$ & 25 & 0.050 & $\mathrm{~W}_{2} \mathrm{~S}_{2} \mathrm{~T}_{2}$ & 16.7 & 0.026 \\
\hline $\mathrm{W}_{1} \mathrm{~S}_{2} \mathrm{~T}_{3}$ & 25.7 & 0.042 & $\mathrm{~W}_{2} \mathrm{~S}_{2} \mathrm{~T}_{3}$ & 12.3 & 0.020 \\
\hline $\mathrm{W}_{1} \mathrm{~S}_{3} \mathrm{~T}_{1}$ & 40.2 & 0.073 & $\mathrm{~W}_{2} \mathrm{~S}_{3} \mathrm{~T}_{1}$ & 28.7 & 0.043 \\
\hline $\mathrm{W}_{1} \mathrm{~S}_{3} \mathrm{~T}_{2}$ & 24.5 & 0.042 & $\mathrm{~W}_{2} \mathrm{~S}_{3} \mathrm{~T}_{2}$ & 16.4 & 0.023 \\
\hline $\mathrm{W}_{1} \mathrm{~S}_{3} \mathrm{~T}_{3}$ & 25.2 & 0.043 & $\mathrm{~W}_{2} \mathrm{~S}_{3} \mathrm{~T}_{3}$ & 11.9 & 0.016 \\
\hline
\end{tabular}

Nowadays, with new developments in agriculture mechanization and also increases in size and weight of machines, soil density has been increased in agricultural practices. This increase in density is more obvious in clay soils, compared to other coarse-textured soils. As a result, the infiltration rate of these compacted soils can be improved using magnetized irrigation water. This practice has other beneficial effects such as reduction of overland runoff and soil-water evaporation (Carbonell et al., 2004).

Analysis of variance presented in Table 5 shows that the effect of magnetized irrigation water and irrigation water salinity on soil electrical conductivity at all soil depths was significant at the $1 \%$ probability level. But soil textures had no significant effect on soil electrical conductivity. The combined effects of soil texture and irrigation water treatment, irrigation water, and irrigation water salinity, soil texture, and irrigation water salinity on soil electrical conductivity were not significant (Table 5).

Table 5: Analysis of variance for soil electrical conductivity

\begin{tabular}{|l|c|c|c|c|}
\hline \multirow{2}{*}{ Parameter } & \multirow{2}{*}{ Degrees of freedom } & \multicolumn{3}{|c|}{ Mean squares } \\
\cline { 3 - 5 } & & $0-20 \mathrm{~cm}$ & $20-40 \mathrm{~cm}$ & $40-60 \mathrm{~cm}$ \\
\hline block & 2 & 0.024 & 0.029 & 0.013 \\
\hline $\mathrm{T}$ & 2 & $0.014^{* *}$ & $0.019^{* *}$ & $0.016^{* *}$ \\
\hline $\mathrm{W}$ & 1 & $0.198^{* *}$ & $0.216^{* *}$ & $0.244^{* *}$ \\
\hline $\mathrm{S}$ & 2 & $0.178^{* *}$ & $0.202^{* *}$ & $0.239^{* *}$ \\
\hline $\mathrm{T} \times \mathrm{W}$ & 2 & $0.010^{\mathrm{ns}}$ & $0.009^{\mathrm{ns}}$ & $0.015^{\mathrm{ns}}$ \\
\hline $\mathrm{T} \times \mathrm{S}$ & 4 & $0.011^{\mathrm{ns}}$ & $0.018^{\mathrm{ns}}$ & $0.016^{\mathrm{ns}}$ \\
\hline $\mathrm{S} \times \mathrm{W}$ & 2 & $0.028^{\mathrm{ns}}$ & $0.031^{\mathrm{ns}}$ & $0.044^{*}$ \\
\hline $\mathrm{T} \times \mathrm{W} \times \mathrm{S}$ & 4 & $0.021^{\mathrm{ns}}$ & $0.015^{\mathrm{ns}}$ & $0.030^{\mathrm{ns}}$ \\
\hline Error & 34 & 0.007 & 0.010 & 0.019 \\
\hline
\end{tabular}

Note: ${ }^{* *}, *$ and ns represent significance at $1 \%$ level, significance at $5 \%$ level and non-significant, respectively

The comparison of average soil electrical conductivity showed that soil electrical conductivity for magnetized water was lower than that for nonmagnetized water (Table 6). The higher soil leaching using magnetized water happened due to higher salt solution capacity in magnetized water and cause lower soil electrical conductivity. Higher soil moisture contents with magnetized water, increase soil salt leaching, and reduce soil salt concentration (Mostafazadeh-Fard et al., 2011).

Table 6: The comparison of average soil electrical conductivity

\begin{tabular}{|l|c|c|c|}
\hline Treatment & $0-20 \mathrm{~cm}$ & $20-40 \mathrm{~cm}$ & $40-60 \mathrm{~cm}$ \\
\hline Soil texture & & & \\
\hline $\mathrm{T}_{1}$ & $7.39 \mathrm{a}$ & $7.76 \mathrm{a}$ & $8.44 \mathrm{a}$ \\
\cline { 2 - 4 } $\mathrm{T}_{2}$ & $7.42 \mathrm{a}$ & $7.81 \mathrm{a}$ & $8.49 \mathrm{a}$ \\
\cline { 2 - 4 } $\mathrm{T}_{3}$ & $7.48 \mathrm{a}$ & $7.80 \mathrm{a}$ & $8.61 \mathrm{a}$ \\
\hline Type of irrigation water & & & \\
\hline $\mathrm{W}_{1}$ & $6.06 \mathrm{~b}$ & $6.89 \mathrm{~b}$ & $7.73 \mathrm{~b}$ \\
\cline { 2 - 4 } $\mathrm{W}_{2}$ & $8.01 \mathrm{a}$ & $8.96 \mathrm{a}$ & $10.05 \mathrm{a}$ \\
\hline Irrigation water salinity & & & \\
\hline $\mathrm{S}_{1}$ & $1.45 \mathrm{c}$ & $1.75 \mathrm{c}$ & $2.22 \mathrm{c}$ \\
\cline { 2 - 4 } $\mathrm{S}_{2}$ & $6.32 \mathrm{~b}$ & $6.89 \mathrm{~b}$ & $7.67 \mathrm{~b}$ \\
\cline { 2 - 4 } $\mathrm{S}_{3}$ & $12.47 \mathrm{a}$ & $13.23 \mathrm{a}$ & $14.89 \mathrm{a}$ \\
\hline
\end{tabular}

In each column, means followed by the same letter are not significantly different at $5 \%$ level
A group scientist analysis displayed that the key properties of magnetized water were the change of the free gas content and the increase of the number of crystallization centers (Bogatin et al., 1999). Degassing of water increases permeability in the soil which causes a considerable enhancement for irrigation efficiency. In some study, stated that the low surface tension and high potential of magnetized water in a solution of some salts, increase the leaching of $\mathrm{Na}$ (Bogatin et al., 1999). Hilal and Hilal stated that sandy loam soil pots irrigated with highly saline water of an electrical conductivity equal to $8.2 \mathrm{mmohs} / \mathrm{cm}$ retained salts compared to pots irrigated with magnetized saline water (Hilal and Hilal, 2000). They showed that magnetic water increased the leaching of excess soluble salts and lowered soil alkalinity (Hilal and Hilal 2000).

A group researchers showed that the magnetic field increases the mobility of the $\mathrm{Na}^{+}$and $\mathrm{Cl}^{-}$ions in different concentration solutions (Chang et al., 2008). In other hand, some researchers reported that laboratory tests have shown that the desalination of a saline soil was $29 \%$ larger in the first leaching and 33\% larger in the second leaching with magnetized water as compared to the non-magnetized water (Zhu et al., 1986). Mohamed and Ebead showed that total salt deletion from the soil after further leachates was significantly improved with magnetized water as compared to the normal water (Mohamed and Ebead, 2013).

Saliha conducted field experiments on the effect of magnetized water on soil chemical and physical properties and concluded a significant reduction in soil EC, $\mathrm{pH}$, and $\mathrm{CaCO}_{3}$ in soil solution (Saliha, 2005). They confirmed the effect of magnetized water on salt leaching and dissolution of $\mathrm{CaCO}_{3}$ and showed that the use of magnetized water for agricultural purposes increases irrigation water quality and improves soil characteristics. Our results are in agreement with those obtained (Saliha, 2005). A studied the effects of magnetized water on soil leaching and concluded higher soil infiltration and reduction of sodium, chloride, and sulfate of soil due to higher soil leaching (Jacob, 1999). The above leaching results are consistent with the results obtained in this paper.

\section{Conclusion}

The high salinity of irrigation water decreases crop yield, or even causes failure of crop establishment, due to specific ion effect, or total salt builds up in the root zone. Therefore, soil amendment for agricultural proposes is essential. The effect of magnetized saline water was studied for three soil textures including loamy-sand, clay, and loam. The final infiltration rate and cumulative water infiltration in these soils increased under magnetized irrigation water. But, the effect was more pronounced in finetextured soils. Therefore, using magnetized irrigation water in finetextured soils is recommendable to improve their water infiltration capacity. Also, magnetized water caused lower soil electrical conductivity as compared to the non-magnetized water. This study showed that magnetized water breaks down the salt crystals faster than nonmagnetically treated water allowing the salt to be leached from the soil.

\section{REFERENCES}

Ajwa, H.A., Trout, T.J., 2006. Polyacrylamide and water quality effects on infiltration in sandy loam soils. Soil Science Society of America Journal, 70 (2), Pp. 643-650.

Baker, J.S., Judd, S.J., 1996. Magnetic amelioration of scale formation. Water Research, 30 (2), Pp. 247-260.

Bogatin, J., Bondarenko, N.P., Gak, E.Z., Rokhinson, E.E., Ananyev, I.P., 1999. Magnetic treatment of irrigation water: experimental results and application conditions. Environmental science \& technology, 33 (8), Pp. 1280-1285.

Bogatin, J., Bondarenko, N.P., Gak, E.Z., Rokhinson, E.E., Ananyev, I.P., 1999. Magnetic treatment of irrigation water: experimental results and application conditions. Environmental science \& technology, 33 (8), Pp. 1280-1285.

Burdukovskii, M., Kiseleva, I., Perepelkina, P., Kosheleva, Y., 2019. Impact of different fallow durations on soil aggregate structure and humus status parameters. Soil and Water Research, 15 (1), Pp. 1-8.

Carbonell, M.V., Martinez, E., Diaz, J.E., Amaya, J.M., Flórez, M., 2004. Influence of magnetically treated water on germination of signalgrass seeds. Seed Science and Technology, 32 (2), Pp. 617-619.

Chang, K.T., Weng, C.I., 2008. An investigation into the structure of aqueous $\mathrm{NaCl}$ electrolyte solutions under magnetic fields. Computational 
Materials Science, 43 (4), Pp. 1048-1055.

Chen, W., Hou, Z., Wu, L., Liang, Y., Wei, C., 2010. Evaluating salinity distribution in soil irrigated with saline water in arid regions of northwest China. Agricultural water management, 97 (12), Pp. 20012008.

Chen, W., Jin, M., Ferré, T.P., Liu, Y., Xian, Y., Shan, T., Ping, X., 2018. Spatial distribution of soil moisture, soil salinity, and root density beneath a cotton field under mulched drip irrigation with brackish and fresh water. Field Crops Research, 215, Pp. 207-221.

Chibowski, E., Szczes, A., Holysz, L., 2005. Influence of sodium dodecyl sulfate and static magnetic field on the properties of freshly precipitated calcium carbonate. Langmuir, 21 (18), Pp. 8114-8122.

Dobrevski, I., Boneva, M., Bonev, B., 1993. Semiindustrial experiments evaluating the effect of the magnetic treatment of cooling water in decreasing deposit formation. Russian Journal of Applied Chemistry, 66 (3).

Du Toit, G.V.N., Snyman, H.A., Malan, P.J., 2009. Physical impact of grazing by sheep on soil parameters in the Nama Karoo subshrub/grass rangeland of South Africa. Journal of Arid Environments, 73 (9), Pp. 804-810.

Fathi, A., Mohamed, T., Claude, G., Maurin, G., Mohamed, B.A., 2006. Effect of a magnetic water treatment on homogeneous and heterogeneous precipitation of calcium carbonate. Water research, 40 (10), Pp. 19411950.

Fentaw, F., Hailu, D., Nigussie, A., Melesse, A.M., 2018. Climate Change Impact on the Hydrology of Tekeze Basin, Ethiopia: Projection of Rainfall-Runoff for Future Water Resources Planning. Water Conservation Science and Engineering, 3 (4), Pp. 267-278.

Fluid Energy Australia Pty, Ltd. 2000. Performance Report on the Application of the TVS-SERIS VORTEX water energizer for leaf vegetable root vegetable and fruiting plants.

Gabrielli, C., Jaouhari, R., Maurin, G., Keddam, M., 2001. Magnetic water treatment for scale prevention. Water Research, 35 (13), Pp. 32493259 .

Gelaye, K.K., Zehetner, F., Loiskandl, W., Klik, A., 2019. Effects of soil texture and groundwater level on leaching of salt from saline fields in Kesem irrigation scheme, Ethiopia. Soil and Water Research, 14 (4), Pp. 221228.

Ghauri, S.A., Ansari, M.S., 2006. Increase of water viscosity under the influence of magnetic field.

Goldsworthy, A., Whitney, H., Morris, E., 1999. Biological effects of physically conditioned water. Water Research, 33 (7), Pp. 1618-1626.

Hemmat, A., Khorsandi, A., Shafaie, V., 2012. Soil failure mode in front of a multiple-tip horizontally operated penetrometer. Turkish Journal of Agriculture and Forestry, 36 (4), Pp. 476-485.

Higashitani, K., Kage, A., Katamura, S., Imai, K., Hatade, S., 1993. Effects of a magnetic field on the formation of $\mathrm{CaCO}_{3}$ particles. Journal of colloid and interface science, 156 (1), Pp. 90-95.

Hilal, M.H., Hilal, M.M., 2000. Application of magnetic technologies in desert agriculture. I-Seed germination and seedling emergence of some crops in a saline calcareous soil. Egyptian Journal of Soil Science, 40 (3), Pp. 413-422.

Hozayn, M., Qados, A.A., 2010. Irrigation with magnetized water enhances growth, chemical constituent and yield of chickpea (Cicer arietinum L.). Agriculture and Biology Journal of North America, 1 (4), Pp. 671-676.

Javadinejad, S., Ostad-Ali-Askari, K., Singh, V.P., Shayannejad, M., 2019. Reliable, Resilient, and Sustainable Water Management in Different
Water Use Sectors. Water Conservation Science and Engineering, 4 (23), Pp. 133-148.

Kang, S., Hao, X., Du, T., Tong, L., Su, X., Lu, H., Ding, R., 2017. Improving agricultural water productivity to ensure food security in China under changing environment: From research to practice. Agricultural Water Management, 179, Pp. 5-17.

Khoshravesh, M., Mostafazadeh-Fard, B., Mousavi, S.F., Kiani, A.R., 2011. Effects of magnetized water on the distribution pattern of soil water with respect to time in trickle irrigation. Soil Use and Management, 27 (4), Pp. 515-522.

Kney, A.D., Parsons, S.A., 2006. A spectrophotometer-based study of magnetic water treatment: Assessment of ionic vs. surface mechanisms. Water Research, 40 (3), Pp. 517-524.

Krouma, A., 2009. Physiological and nutritional responses of chickpea (Cicer arietinum L) to salinity. Turkish Journal of Agriculture and Forestry, 33 (5), Pp. 503-512.

Liu, Y., Guo, L., Huang, Z., López-Vicente, M., Wu, G.L., 2020. Root morphological characteristics and soil water infiltration capacity in semi-arid artificial grassland soils. Agricultural Water Management, 235, Pp. 106153.

Luo, J., He, W., Qi, S., Wu, J., Gu, X.S., 2020. A novel phytoremediation method assisted by magnetized water to decontaminate soil $\mathrm{Cd}$ based on harvesting senescent and dead leaves of Festuca arundinacea. Journal of hazardous materials, 383, Pp. 121115.

Madsen, H.E.L., 2004. Crystallization of calcium carbonate in magnetic field in ordinary and heavy water. Journal of Crystal Growth, 267 (1-2), Pp. 251-255.

Madsen, H.L., 1995. Influence of magnetic field on the precipitation of some inorganic salts. Journal of Crystal Growth, 152 (1-2), Pp. 94-100.

Mohamed, A.I., Ebead, B.M., 2013. Effect of magnetic treated irrigation water on salt removal from a sandy soil and on the availability of certain nutrients. International Journal of Engineering, 2 (2), Pp. 2305-8269.

Mostafazadeh-Fard, B., Khoshravesh, M., Mousavi, S.F., Kiani, A.R., 2011. Effects of magnetized water and irrigation water salinity on soil moisture distribution in trickle irrigation. Journal of Irrigation and Drainage Engineering, 137 (6), Pp. 398-402.

Öğütçü, H., Kasimoğlu, C., Elkoca, E., 2010. Effects of Rhizobium strains isolated from wild chickpeas on the growth and symbiotic performance of chickpeas (Cicer arietinum L.) under salt stress. Turkish Journal of Agriculture and Forestry, 34 (5), Pp. 361-371.

Pang, X., Deng, B., 2008. Investigation of changes in properties of water under the action of a magnetic field. Science in China Series G: Physics, Mechanics and Astronomy, 51 (11), Pp. 1621-1632.

Parsons, S.A., Wang, B.L., Judd, S.J., Stephenson, T., 1997. Magnetic treatment of calcium carbonate scale-effect of $\mathrm{pH}$ control. Water Research, 31 (2), Pp. 339-342.

Radcliffe, D.E., Rasmussen, T.C., 2000. Soil water movement. In Handbook of Soil Science, Ed., Sumner, M.E. CRC Press, TX.

Saliha, B.B., 2005. Bioefficacy testing of GMX online magnetic water conditioner in grapes var. muscat. Tamil Nadu agricultural university. Project Completion Project.

Srivastava, S.C., Lal, P.B.B., Sharma, B.N., 1977. Application of solar energy in conjunction with magnetized water to boost food output. In National Solar Energy Convention, Pp. 248-250.

Zhu, T.Y., Sheng, D.G., Han, C.J., Liu, H.W., 1986. Studies on the effectiveness of magnetized water in improving saline soils. Irrigation Drainage Abstracts.

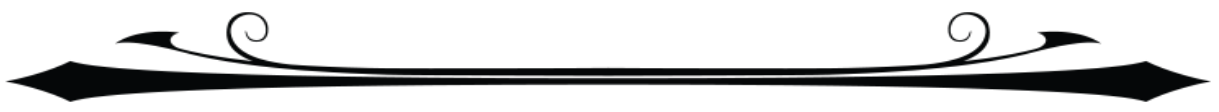

